Al-Tanzim : Jurnal Manajemen Pendidikan Islam

E-ISSN: 2549-5720 P-ISSN: 2549-3663

March 2019, Vol. 03 No. 01, p. 169-197

bttps: / / journal.unuja.ac.id/ index.php/ al-tanzim

\title{
MANAJEMEN STRATEGI DALAM MENINGKATKAN MUTU PELAYANAN KEPEGAWAIAN
}

\author{
Hefniy \& Refi Najma Fairus \\ Universitas Nurul Jadid, Probolinggo \\ reynafacute@gmail.com
}

\section{Abstract :}

Strategy Management in improving the quality of staffing services in the Probolinggo District Education Office. The purpose of this article was to study the management of strategies carried out by the Education Office of Probolinggo District specifically service personnel and the quality of staffing services from the implementation of the management strategies in the Probolinggo District Education Office. This study uses qualitative methods with a type of case study research. The data analysis used is the Interactive analysis model of Miles and Huberman. The results is showed that the management strategy carried out by the Probolinggo District Education Office was also applied to staffing services guided by the Provincial RPJP and Probolinggo District RPJMD using a strategic planning process, implementing strategies and evaluation strategies. And the quality of the Probolinggo District Education Office staffing services after the strategy management has been fairly good with reference to the fulfillment of five service standards.

Key words : Strategy Management, Public Service, Quality of Service, Staffing Services. 
Al-Tanzim : Jurnal Manajemen Pendidikan Islam

E-ISSN: 2549-5720 P-ISSN: 2549-3663

March 2019, Vol. 03 No. 01, p. 169-197

bttps:// ejournal.unuja.ac.id/index.php/al-tanzim

\section{Abstrak :}

Manajemen Strategi dalam meningkatkan mutu pelayanan kepegawaian di Dinas Pendidikan Kabupaten Probolinggo. Tujuan penelitian ini untuk mengetahui manajemen strategi yang dilakukan Dinas Pendidikan Kabupaten Probolinggo khususnya pelayanan kepagawaian dan mutu pelayanan kepegawaian dari diterapkannya manajemen strategi tersebut di Dinas Pendidikan Kabupaten Probolinggo. Penelitian ini menggunakan metode penelitian kualitatif dengan jenis penelitian studi kasus. Analisis data yang digunakan adalah model analisis Interaktif Miles dan Huberman. Hasil penelitian menunjukkan bahwa Manajemen strategi yang dilakukan Dinas Pendidikan Kabupaten Probolinggo juga diterapkan pada pelayanan kepegawaian dengan berpedoman kepada RPJP Propinsi dan RPJMD Kabupaten Probolinggo ditempuh dengan proses tahapan perencanaan strategi, pelaksanaan strategi dan evaluasi strategi. Dan mutu pelayanan kepegawaian Dinas Pendidikan Kabupaten Probolinggo setelah dilakukan manajemen strategi sudah terbilang baik yang terbukti dengan mangacu pada terpenuhinya lima dimensi pokok mutu layanan.

Kata Kunci : Manajemen Strategi, Pelayanan Publik, Mutu Pelayanan, Pelayanan Kepegawaian.

\section{PENDAHULUAN}

Pelayanan publik masih menjadi masalah dalam birokrasi di Indonesia, banyak faktor dan ragam yang menyebabkan hal tersebut menjadi masalah di sudut pandang masyarakat. Kebutuhan masyarakat saat ini cenderung besar dengan keinginan untuk mendapatkan pelayanan yang cepat dan tepat. 
Al-Tanzim : Jurnal Manajemen Pendidikan Islam

E-ISSN: 2549-5720 P-ISSN: 2549-3663

March 2019, Vol. 03 No. 01, p. 169-197

https:// ejournal.unuja.ac.id/index.php/al-tanzim

Pemerintah yang mendapat kepercayaan dari masyarakat sebagai pemegang kekuasaan saat ini memiliki tanggungjawab penting untuk memenuhi harapan dan kebutuhan masyarakat dengan melayani jasa publik tanpa membeda-bedakan suku, agama, golongan, ras dan lainnya Taufiqurokhman, 2018).

Kelancaran pelaksanaan pembangunan pelayanan Nasional tergantung kepada kesempurnaan dari Aparatur Negara, dan kualitas Aparatur Negara tergantung kepada kesempurnaan Pegawai Negeri. Maka, Pegawai Negeri Sipil (PNS) merupakan salah satu subjek pelaku utama dalam pelaksanaan pembangunan pelayanan. Sesuai dengan UU 1945 pemerintah pusat memberikan kewenangannya kepada pemerintah daerah untuk menyelenggarakan segala urusan pemerintahannya sendiri. Dinas Pendidikan Kabupaten Probolinggo merupakan salah satu lembaga non profit yang menjadi aparatur penyedia layanan publik daerah yang mengurus seluruh urusan di sektor pendidikan. Bagian pelayanan kepegawaian mempunyai tugas pokok merencanakan, melaksanakan, mengevaluasi dan melaporkan pelaksanaan tugas pelayanan administrasi kepegawaian di lingkungan Dinas Pendidikan Kabupaten Probolinggo.

Suatu pelayanan dapat dikatakan bermutu bergantung pada bagaimana tata laksana, dukungan sumberdaya manusia, dan kelembagaannya. Praktisnya, 
Al-Tanzim : Jurnal Manajemen Pendidikan Islam

E-ISSN: 2549-5720 P-ISSN: 2549-3663

March 2019, Vol. 03 No. 01, p. 169-197

https:/ / ejournal.unuja.ac.id/ index.php/ al-tanzim

Masyarakat hanya menginginkan prosedur yang mudah, sederhana dan tidak banyak menghabiskan waktu. Sampai saat ini, salah satu tugas utama yang belum terpecahkan ialah perbaikan terhadap pelayanan.

Untuk memperbaiki dan menyempurnakan kegiatan penyelenggaraan pelayanan publik, solusi tepat ialah pengimplementasian manajemen strategi yang diharapkan menjadi pengarah dan pengendali terhadap setiap perubahan kondisi nanti yang akan diterima oleh penyedia layanan. Dengan demikian, dapat menganalisis setiap kelebihan organisasi, setiap kelemahan yang dimiliki, setiap ancaman yang akan memperburuk citra organisasi, dan setiap peluang yang bisa dimanfaatkan sebagai tolak ukur peningkatan mutu pelayanan.

Maka perbaikan pelayanan dapat dilakukan dengan digunakannya manajemen strategi oleh Dinas Pendidikan Kabupaten Probolinggo khususnya pada sub bagian pelayanan kepegawaian, dan diketahui pula pencapaian mutu pelayanan kepegawaian dari manajemen strategi yang sudah dilakukan oleh Dinas Pendidikan Kabupaten Probolinggo.

\section{MANAJEMEN STRATEGI}

Pada hakikatnya, manajemen merupakan proses penggunaan sumber daya secara efektif untuk mencapai sasaran atau tujuan tertentu (Taufiqurokhman \& Evi Satispi, 
Al-Tanzim : Jurnal Manajemen Pendidikan Islam

E-ISSN: 2549-5720 P-ISSN: 2549-3663

March 2019, Vol. 03 No. 01, p. 169-197

https:/ / ejournal.unuja.ac.id/ index.php/ al-tanzim

2018). Manajemen strategi ialah pengelolaan mengenai formulasi, implementasian serta evaluasi kebijakan terkait strategi yang mengarahkan organisasi kepada tujuannya tercapai. Pengertian lain dari Lawrence R. Jauch dan William F. Gluech tentang manajemen strategi ialah beberapa kebijakan serta kegiatan yang menuju kepada perumusan sebuah strategi bahkan hingga beberapa strategi yang efektif untuk mendorong pencapaian target organisasi.

Secara umum, manajemen strategi memiliki tiga proses manajemen, yaitu (Kurniawan, 2016):

a. Tahap Formulasi Strategi: meliputi pembuatan visi, misi tujuan dan sasaran, pengidentifikasian faktor internal dan eksternal organisasi, pembuatan rencana jangka menengah dan panjang, dan pembuatan strategi untuk diterapkan.

b. Tahap Implementasi Strategi: meliputi menentukan kebijakan, memotivasi sumber daya manusia organisasi, mengalokasikan sumber daya supaya perumusan strategi tersebut bisa diselenggarakan.

c. Tahap Evaluasi Strategi: meliputi memonitor seluruh hasil dari perumusan dan implementasi strategi, pengukuran kinerja, dan pengambilan tindakan perbaikan. 
Al-Tanzim : Jurnal Manajemen Pendidikan Islam

E-ISSN: 2549-5720 P-ISSN: 2549-3663

March 2019, Vol. 03 No. 01, p. 169-197

https:// ejournal.unuja.ac.id/ index.php/al-tanzim

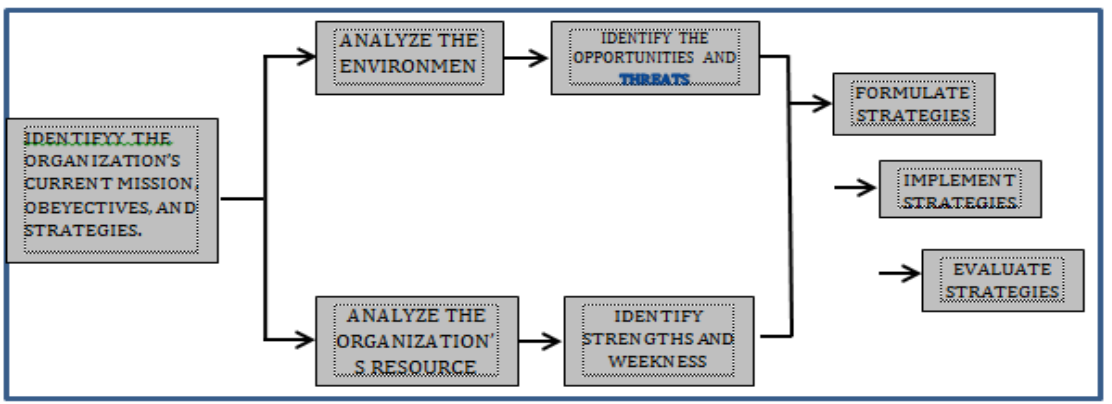

Gambar 1:

Proses manajemen strategi(Taufiqurokhman, 2016)

Manajemen strategi sebagai sebuah kerangka kerja untuk menyelesaikan masalah dalam organisasi, yang utama mengenai persaingan. Seluruh unsur organisasi didorong berpikir secara kreatif. Manfaat yang diperoleh dalam menerapkan manajemen strategi adalah (Saleh, 2016):

a. Memberikan arah dan tujuan jangka panjang organisasi secara jelas dan transparan.

b. Membantu manajer dalam melakukan perubahan dan strategi dalam meningkatkan kemampuan organisasi guna mencegah masalah muncul di masa depan.

c. Membuat kegiatan organisasi menjadi lebih efektif dan efisien dalam menggunakan sumber daya.

d. Mengidentifikasi berbagai keunggulan komparatif dalam lingkungan organisasi.

e. Melibatkan anggota dalam membuat strategi, sehingga anggota organisasi dapat termotivasi pada saat pelaksanaannya. 
Al-Tanzim : Jurnal Manajemen Pendidikan Islam

E-ISSN: 2549-5720 P-ISSN: 2549-3663

March 2019, Vol. 03 No. 01, p. 169-197

https:/ / ejournal.unuja.ac.id/ index.php/ al-tanzim

f. Mengurangi kegiatan atau aktifitas yang tumpang tindih dari masing-masing unit organisasi.

\section{MUTU PELAYANAN}

Mutu pelayanan menjadi penyelarasan dengan ukuran keberhasilan yang akan dicapai. Terdapat dua faktor analisis mutu pelayanan adalah kinerja pelayanan dan pelayanan yang diharapkan pelanggan. Supaya penerima layanan memiliki pandangan yang baik dan merasa puas kepada mutu pelayanan yang diterima, maka harapan mereka menjadi suatu yang seharusnya diketahui oleh penyedia layanan. Sehingga tidak ada perbedaan antara pelayanan yang diberikan dengan harapan penerima layanan (Wijaya, 2013).

Dimensi mutu layanan dapat dilihat pada 5 dimensi pokok, yakni:

a. Bukti langsung (tangibles), berupa fasilitas fisik, perlengkapan, pegawai dan komunikasi.

b. Kehandalan (reliability), yakni penyedia layanan mampu melayani secara cepat, akurat serta memberikan kepuasan.

c. Daya tanggap (responsiveness), meliputi kemauan para penyedia layanan untuk membantu para pengguna layanan serta melayani dengan tanggap. 
Al-Tanzim : Jurnal Manajemen Pendidikan Islam

E-ISSN: 2549-5720 P-ISSN: 2549-3663

March 2019, Vol. 03 No. 01, p. 169-197

https:// ejournal.unuja.ac.id/index.php/al-tanzim

d. Jaminan (assurance), meliputi pengetahuan, kemampuan, dan sifat dapat dipercaya yang dimiliki oleh para penyedia layanan, bebas dari bahaya atau keraguan.

e. Empati (emphaty), mencakup kemudahan dalam melakukan interaksi yang baik, perhatian pribadi serta mengetahui kebutuhan pengguna layanan (Taufiqurokhman, 2016).

Hakikatnya, terdapat tiga pengukuran dasar dalam mengetahui baik buruknya mutu pelayanan dengan perlu memperhatikan keseimbangan antara:

a. Komponen antar pribadi yang melaksanakan (Inter Personal Component);

b. Komponen proses dengan lingkungan yang mempengaruhi (Process and Environment);

c. Komponen profesional dengan sistem yang digunakan (Professional and Technical)

\section{PELAYANAN KEPEGAWAIAN}

Pelayanan administrasi kepegawaian adalah salah satu pelayanan publik yang terbilang sering menjadi sorotan baik pelayanan kepada pelanggan internal maupun pelanggan eksternal organisasi. Pelayanan administrasi kepegawaian sangat dibutuhkan karena adanya kebutuhan dan hak pegawai yang berkembang. Pelayanan yang diberikan oleh administrasi kepegawaian menyangkut nasib pegawai negeri sipil dan pegawai aparatur pemerintah 
Al-Tanzim : Jurnal Manajemen Pendidikan Islam

E-ISSN: 2549-5720 P-ISSN: 2549-3663

March 2019, Vol. 03 No. 01, p. 169-197

https:/ / ejournal.unuja.ac.id/ index.php/ al-tanzim

dalam skala yang besar (Hisbanarto, 2014)

Dengan demikian, disebutkan dalam Peraturan Pemerintah Republik Indonesia Nomor 11 Tahun 2017 Tentang Manajemen Pegawai Negeri Sipil Pasal 1 Ayat 4, bahwa pelayanan yang baik dan berkualitas harus memiliki unsur cepat, responsif, akurat, dan mengikuti prosedur yang telah ditetapkan. Kualitas pelayanan pegawai yang menunjukkan kinerja yang ditampilkan dapat dilihat pada lima dimensi pelayanan publik pada umumnya. Orientasi pelayanan ialah perilaku kerja pegawai dalam melayani yang terbaik antara lain terhadap masyarakat, atasan, teman kerja, dan unit kerja terkait.

Adapun uraian tugas bagi jabatan administrasi kepegawaian, ialah:

a. Mengendalikan kelengkapan data mutasi kepegawaian

b. Menyiapkan usul persetujuan pertimbangan teknis penetapan Nomor Induk Pegawai, kenaikan pangkat, usul pemindahan mutasi pegawai, berita acara sumpah jabatan, surat pernyataan melaksanakan tugas, naskah keputusan kenaikan pangkat atau konsep naskah SK Pensiun Pegawai

c. Mendokumentasikan berkas KP dan pensiun sesuai dengan peraturanjuga kebijakan yang berlaku, agar tertib administrasi

d. Menjalankan tugas kedinasan lain yang diperintahkan oleh pimpinan tertulis maupun lisan. 
Al-Tanzim : Jurnal Manajemen Pendidikan Islam

E-ISSN: 2549-5720 P-ISSN: 2549-3663

March 2019, Vol. 03 No. 01, p. 169-197

https:// ejournal.unija.ac.id/ index.php/al-tanzim

\section{METODE PENELITIAN}

Penelitian ini menggunakan pendekatan kualitatif dengan jenis penelitian studi kasus. Lokasi penelitian yang peneliti lakukan yaitu di Dinas Pendidikan Kabupaten Probolinggo tepatnya pada Subbagian pelayanan kepegawaian. Teknik pengumpulan data yang dipakai yaitu observasi, interview, dan dokumentasi. Analisis data yang digunakan adalah model analisis interaktif dari Miles dan Huberman yang terdiri dari pengumpulan data, reduksi data, penyajian data, dan penarikan kesimpulan.

\section{HASIL PENELITIAN DAN PEMBAHASAN}

\section{Manajemen Strategi dalam Pelayanan Kepegawaian}

Pelayanan Kepegawaian Dinas Pendidikan Kabupaten Probolinggo telah menerapkan prosedur pelayanan yang mudah bagi pengguna layanan yang ingin mengurus keperluannya. Sebagaimana dalam Peraturan Kepala Badan Kepegawaian Negara Nomor 20 Tahun 2015 Tentang Uraian Tugas jabatan pelaksana di Lingkungan Badan Kepegawaian Negara yang menyusun rencana dan program kerja operasional kegiatan pelayanan administrasi kepegawaian. Secara umum, manajemen strategi memiliki tiga proses manajemen, yaitu: Tahap Formulasi Strategi, tahap implementasi strategi, dan tahap evaluasi strategi (Pratama, 2015). 
Al-Tanzim : Jurnal Manajemen Pendidikan Islam

E-ISSN: 2549-5720 P-ISSN: 2549-3663

March 2019, Vol. 03 No. 01, p. 169-197

https:/ / ejournal.unuja.ac.id/ index.php/ al-tanzim

\section{a. Perencanaan Strategi atau Formulasi Strategi}

Perencanaan adalah penentuan secara matang dan cerdas tentang apa yang akan dikerjakan di masa yang akan dating dalam rangka mencapai tujuan pada setiap satuan dan jenjang pendidikan (LAN, 2009)

1) Perumusan visi, misi, tujuan, dan sasaran

Dalam tahap ini, merumuskan visi, misi, tujuan dan sasaran sebagai pedoman pelaksanaan pelayanan yang ingin dicapai.Bahwa dapat diketahui, sehubungan dengan perumusan visi, misi, tujuan dan juga sasaran Dinas Pendidikan Kabupaten Probolinggo sendiri, pelayanan kepegawaian juga menetapkan visi, yakni “TERWUJUDNYA PELAYANAN PRIMA SESUAI PROSEDUR TANPA PUNGUTAN BIAYA". Hal ini benar-benar diwujudkan dengan motto yang tertera di atas pintu pelayanan kepegawaian sehingga mencipatakan birokrasi yang bersih dan tanpa tekanan untuk siapapun.

Misinya yaitu untuk mewujudkan pelayanan yang prima sesuai prosedur tanpa dipungut biaya dan merealisasikan proses pelayanan umum, administrasi pemerintahan dan pembangunan serta kepegawaian berbasis informasi teknologi. Dengan tujuan yang ingin 
Al-Tanzim : Jurnal Manajemen Pendidikan Islam

E-ISSN: 2549-5720 P-ISSN: 2549-3663

March 2019, Vol. 03 No. 01, p. 169-197

https:/ / ejournal.unuja.ac.id/ index.php/ al-tanzim

tercapainya misi-misi tersebut. Sasaran strategis adalah penjabaran dari tujuan itu sendiri. sasarannya ialah kepuasan penerima layanan.

2) Mengidentifikasi Faktor Internal dan Eksternal Pelayanan Kepegawaian

Tahap ini melakukan reset yang dilaksanakan dengan adanya anggaran sebagai penerimaan pendapat, saran bahkan keluhan penerima layanan yang diberikan kepada pelayanan kepegawaian. Upaya ini ditujukan untuk perumusan strategi selanjutnya sehingga mengenai sasaran. Riset yang dilakukan hingga saat ini ialah dengan disediakan kotak saran untuk penerima layanan.

Table 1 :

Identifikasi Faktor Internal (Kekuatan \& Kelemahan) pada Sub Bagian Pelayanan Umum \& Kepegawaian

\begin{tabular}{|r|l|l|}
\hline NO & KEKUATAN & KELEMAHAN \\
\hline 1 & $\begin{array}{l}\text { Tertib administrasi yang } \\
\text { sesuai prosedur pelayanan }\end{array}$ & $\begin{array}{l}\text { Masih kurangnya } \\
\text { memahami tugas } \\
\text { individu }\end{array}$ \\
\hline 2 & $\begin{array}{l}\text { Terjalinnya kebersamaan \& } \\
\text { kerja sama team yang kuat. }\end{array}$ & $\begin{array}{l}\text { Masih kurangnya } \\
\text { sarana penunjang } \\
\text { administrasi seperti } \\
\text { printer dan mesin }\end{array}$ \\
\hline
\end{tabular}


Al-Tanzim : Jurnal Manajemen Pendidikan Islam

E-ISSN: 2549-5720 P-ISSN: 2549-3663

March 2019, Vol. 03 No. 01, p. 169-197

https:/ / ejournal.unija.ac.id/ index.php/ al-tanzim

\begin{tabular}{|c|l|l|}
\hline 3 & $\begin{array}{l}\text { Adanya peningkatan } \\
\text { upaya peningkatan } \\
\text { penyelenggaraan } \\
\text { administrasi yang semakin } \\
\text { terbuka dan peningkatan } \\
\text { kualitas pelayanan public }\end{array}$ & $\begin{array}{l}\text { Masih terdapatnya } \\
\text { pegawai ASN yang } \\
\text { memiliki kemampuan } \\
\text { yang kurang } \\
\text { memadai/professional } \\
\text { sesuai bidang } \\
\text { tugas/fungsi yang } \\
\text { diembannya }\end{array}$ \\
\hline 4 & $\begin{array}{l}\text { Tersedianya sumber daya } \\
\text { manusia pada Dinas } \\
\text { Pendidikan Kabupaten } \\
\text { Probolinggo yang relatif } \\
\text { cukup }\end{array}$ & \\
\hline
\end{tabular}

Table 2 :

Identifikasi Faktor Eksternal (Ancaman \& Peluang) pada Sub Bagian Pelayanan Umum \& Kepegawaian

\begin{tabular}{|l|l|l|}
\hline NO & \multicolumn{1}{|c|}{ ANCAMAN } & \multicolumn{1}{c|}{ PELUANG } \\
\hline 1 & Makin tingginya & Potensi teknologi \\
& persaingan kualitas & komunikasi sebagai sumber \\
& SDM antar wilayah & yang dapat dimanfaatkan \\
& dan antar negara di & untuk memecahkan \\
& dunia & permasalahan- \\
& & permasalahan \\
\hline
\end{tabular}


Al-Tanzim : Jurnal Manajemen Pendidikan Islam

E-ISSN: 2549-5720 P-ISSN: 2549-3663

March 2019, Vol. 03 No. 01, p. 169-197

https:// ejournal.unija.ac.id/ index.php/al-tanzim

3) Mengidentifikasi Rencana Menengah dan Panjang

Tahap ini mengidentifikasi rencana menengah dan panjang dari pelayanan kepegawaian yang hanya melaksanakan dari Rencana Kerja Dinas Pendidikan Kabupaten Probolinggo dengan mengacu kepada RPJP Propinsi dan RPJMD Kabupaten Probolinggo. Akan tetapi Pelayanan kepegawaian tetap berusaha melaksanakan Renja Dinas Pendidikan Kabupaten Probolinggo dengan efektif dan partisipatif.

4) Membuat Strategi yang akan Diterapkan

Sama halnya dengan rencana, strategi yang ditetapkan juga disesuaikan dengan RPJMD Kabupaten Probolinggo yang berakhlak mulia melalui peningkatan Nilai Indeks Kepuasan Masyarakat dengan penyediaan jasa administrasi kepegawain dan penyediaan sarana prasarana perkantoran. Untuk pencapaian nilai indeks kepuasan masyarakat, strategi Dinas Pendidikan Kabupaten Probolinggo memisahkan ruangan pelayanan kepegawaian dari ruangan tenaga kependidikan dan merelokasikan ruangan pelayanan kepegawaian di samping pelayanan umum. 
Al-Tanzim : Jurnal Manajemen Pendidikan Islam

E-ISSN: 2549-5720 P-ISSN: 2549-3663

March 2019, Vol. 03 No. 01, p. 169-197

bttps: / / journal.unuja.ac.id/ index.php/ al-tanzim

\section{b. Pelaksanaan Strategi atau Implementasi Strategi}

1) Menentukan Kebijakan

Kebijakan merupakan arah yang diambil oleh Dinas Pendidikan Kabupaten Probolinggo dalam menentukan bentuk konfigurasi program dan kegiatan untuk mencapai tujuan.Untuk mewujudkan peningkatan tata kelola layanan pendidikan yang transparan dan akuntabel berbasis teknologi informasi, Dinas Pendidikan Kabupaten Probolinggo mengeluarkan kebijakan melalui program untuk pelayanan administrasi kepegawaian, yang berupa Program Pelayanan Administrasi Perkantoran yang ditempuh dengan 2 indikator yaitu penyediaan jasa administrasi kepegawaian dan penyediaan jasa sarana dan prasarana kantor.

Upaya yang telah dilakukan ialah relokasi ruangan pelayanan kepegawaian ditujukan untuk memudahkan akses pegawai yang berkebutuhan dan mencapai nilai indeks kepuasan masyrakat. tidak hanya itu, kebijakan yang berupa prosedur tata laksana pelayanan baru juga ditetapkan oleh Dinas Pendidikan Kabupaten Probolinggo terhadap pelayanan kepegawaian untuk perbaikan prosedur lama yang direalisasikan sampai saat ini. 
Al-Tanzim : Jurnal Manajemen Pendidikan Islam

E-ISSN: 2549-5720 P-ISSN: 2549-3663

March 2019, Vol. 03 No. 01, p. 169-197

https:// ejournal.unuja.ac.id/ index.php/al-tanzim

2) Memotivasi Pegawai Pelayanan Kepegawaian

Dalam tahap ini, peran Kepala Dinas menjadi sumber utama dari pemberian motivasi dengan mengadakan form interaksi bersama seluruh pegawai di Dinas Pendidikan Kabupaten Probolinggo. Akan tetapi, seorang Sekretaris juga berwewenang untuk memotivasi yang membawahi Sub Bagian Umum \& Kepegawaian salah satunya. Adanya reward dan punishment juga diberlakukan dan tetap digunakan sebagai wujud penghargaan atau peringatan untuk kinerja pegawai. Seperti mutasi unit kerja sebagai peringatan dan penghargaan terhadap pegawai.

3) Mengalokasikan Sumber Daya di Pelayanan Kepegawaian

Tahap ini dilakukan dengan cara segmentasi kemamupan personal/individu pegawai agar dapat melaksanakan tugas sesuai dengan kemampuan dan keahliannya. Cara pengembangan kompetensi pegawai ialah dengan memberikan pembinaan atau workshop. Walau ada beberapa lulusan pegawai yang direkrut tidak sesuai dengan bidang pekerjaannya tetapi ahli dan mempunyai kemampuan dalam tugas yang diembannya. 
Al-Tanzim : Jurnal Manajemen Pendidikan Islam

E-ISSN: 2549-5720 P-ISSN: 2549-3663

March 2019, Vol. 03 No. 01, p. 169-197

https:/ / ejournal.unuja.ac.id/ index.php/ al-tanzim

\section{c. Evaluasi Evaluasi Manajemen Srategi Pelayanan} Kepegawaian

1) Memonitor seluruh hasil dari perumusan dan penerapan strategi di Pelayanan Kepegawaian

Pada tahap ini, Dinas Pendidikan Kabupaten Probolinggo Mengadakan monitor dan evaluasi terhadap pencapaian hasil program \& kegiatan serta dalam hal akses mutu layanan. Sedangkan upaya khusus yang dilakukan oleh pelayanan Kepegawaian ialah dimonitoring / disupervisi sendiri oleh seorang Sekretaris. Sedangkan peran Kepala Sub Bagian juga difungsikan untuk lebih intensif dalam memonitor staff bawahannya dengan melakukan diskusi/rapat intern per minggunya untuk mengetahui kinerja yang telah dilakukan dan kekurangan/kesalahan apa yang dirasakan dengan mencatat di buku catatan mereka masingmasing.

2) Mengukur Kinerja Individu Pegawai

Dinas Pendidikan memiliki prosedur birokrasi dalam pengukuran kinerja pegawai melalui penjanjian dan sasaran kinerja pegawai (SKP) dari para staff hingga para eselon untuk meningkatkan produktifitas para pegawai dan dapat mempertanggungjawabkan kinerjanya. 
Al-Tanzim : Jurnal Manajemen Pendidikan Islam

E-ISSN: 2549-5720 P-ISSN: 2549-3663

March 2019, Vol. 03 No. 01, p. 169-197

https:// ejournal.unija.ac.id/ index.php/al-tanzim

Tahapan ini diupayakan untuk pencapaian sasaran yang sesuai dengan rencana.

3) Mengambil Langkah-langkah Perbaikan

Secara umum, langkah perbaikan Dinas Pendidikan Kabupaten Probolinggo dari sasaran yang ditetapkan dalam Renstra tahun 2014-2019 untuk tahun 2018 sudah dapat dilaksanakan seluruhnya. Telah menjadi tugas utama organisasi dapat melaksanakan tanggung jawabnya.Dan dengan bukti mereview 15 program menjadi 10 program untuk tahun 2019.

2. Mutu Pelayanan Kepegawaian Dinas Pendidikan Kabupaten Probolinggo setelah Diterapkannya Manajemen Strategi

Mutu pelayanan Kepegawaian Dinas Pendidikan Kabupaten Probolinggo pada penelitian inidapat dilihat sesuai dengan 5 dimensi pokok mutu pelayanan publik berdasarkan dengan tinjauan pustaka. yaituTangible (Berwujud), Reliability (Kehandalan), Responsiviness (Ketanggapan), Assurance (Jaminan), dan Emphaty (Empati). Dalam rangka mengelola organisasi pendidikan secara efektif dalam upaya mencapai tujuannya, diperlukan manajemen modern yang dapat mempercepat ketersediaan output dan outcome unggul 
Al-Tanzim : Jurnal Manajemen Pendidikan Islam

E-ISSN: 2549-5720 P-ISSN: 2549-3663

March 2019, Vol. 03 No. 01, p. 169-197

https:/ / ejournal.unuja.ac.id/ index.php/ al-tanzim

sebagaimana yang diharapkan (Mundiri, 2016). Dengan penjelasan sebagai berikut:

\section{a. Dimensi Tangible}

1) Penampilan pegawai saat melayani penerima layanan

Dalam pelayanan publik, hal yang diharapkan dan yang harus dicapai ialah kualitas pelayanan. Pada dimensi ini, pelayanan yang baik dapat dilihat dari usaha Pelayanan Kepegawaian Dinas Pendidikan Kabupaten Probolinggo yang menyesuaikan penampilan dengan seragam dan rapi. Sebagai lembaga pembantu Daerah, usaha ini dilakukan karena bagi masyarakat hal ini menjadi kesan pertama dan dimaksudkan agar menciptakan citra baik.

2) Disiplin pegawai dalam proses pelayanan

Tak hanya penampilan rapi dan sesuai seragam, kedisiplinan pegawai Pelayanan Kepegawaian Dinas Pendidikan Kabupaten Probolinggo juga mempengaruhi kualitas pelayanan. Dengan kegiatan apel setiap pagi sebelum melaksanakan kerja, adanya absen apel pagi dan fingerprint dimaksudkan untuk mengetahui dan mengukur keaktifan dan kehadiran pegawai setiap harinya.Untuk semua usaha yang sudah dilakukan Dinas Pendidikan 
Al-Tanzim : Jurnal Manajemen Pendidikan Islam

E-ISSN: 2549-5720 P-ISSN: 2549-3663

March 2019, Vol. 03 No. 01, p. 169-197

https:// ejournal.unuja.ac.id/ index.php/al-tanzim

Kabupaten Probolinggo, pegawai sudah disiplin dalam pekerjaan menggunakan waktunya sehingga kondusif dalam bekerja.

3) Kenyamanan tempat pelayanan

Kenyamanan lingkungan juga menjadi tolak ukur dalam pencapaian pelayanan yang bermutu dan memuaskan pengguna layanan di pelayanan kepegawaian Dinas Pendidikan Kabupaten Probolinggo. Karena apabila penerima layanan mendapat kenyamanan lingkungan yang berkaitan dengan lokasi atau ruang pelayanan, ketersediaan informasi, dan sarana prasarana untuk mereka, maka pelayanan kepegawaian mencapai kepada Nilai Indeks Kepuasan Masyarakat.

Salah satu bentuk kebijakan yang dilakukan Dinas Pendidikan Kabupaten Probolinggo terhadap pelayanan kepegawain ialah merelokasi ruangan pelayanan kepegawaian di sebelah ruangan pelayanan umum yang awalnya menyatu satu ruangan dengan bidang tenaga kependidikan. Tak hanya itu, perlengkapan sarana seperti tempat duduk untuk menunggu antrian dan pendingin ruangan seperti AC juga dimaksudkan untuk mencapai kepeuasan pengguna layanan. 
Al-Tanzim : Jurnal Manajemen Pendidikan Islam

E-ISSN: 2549-5720 P-ISSN: 2549-3663

March 2019, Vol. 03 No. 01, p. 169-197

bttps: / / journal.unuja.ac.id/ index.php/ al-tanzim

4) Kemudahan dalam pelayanan

Kemudahan prosedur dalam pelayanan sangat diharapkan oleh masyarakat dan mempengaruhi juga terhadap mutu pelayanan. Mempermudah mereka merupakan tujuan utama bagi pelayanan kepegawaian Dinas Pendidikan Kabupaten Probolinggo. Tak jarang masyarakat masih saja kurang mengerti dan mengetahui persyaratan atau kelengkapan berkas administrasi kepegawian, akan tetapi pegawai pelayanan kepegawaian tetap berusaha menghargai dan membuat mereka mengerti tentang kekurangan berkas dari masyarakat tersebut.

\section{b. Dimensi Reliability}

Pelayanan Kepegawaian Dinas Pendidikan Kabupaten Probolinggo senantiasa dituntut untuk kemampuannya meningkatkan kualitas personal pegawai dalam pelayanan. Kehandalan dapat diartikan mengerjakan dengan benar sesuai dengan prosedur kerja atau standar pelayanan dan mengerjakan dengan menggunakan alat bantu.

1) Kehandalan pegawai dalam menggunakan alat bantu dalam proses pelayanan

Dengan adanya kegiatan penyediaan sarana prasarana kantor seperti komputer yang ditetapkan oleh Dinas Pendidikan Kabupaten 
Al-Tanzim : Jurnal Manajemen Pendidikan Islam

E-ISSN: 2549-5720 P-ISSN: 2549-3663

March 2019, Vol. 03 No. 01, p. 169-197

https:// ejournal.unuja.ac.id/ index.php/al-tanzim

Probolinggo, maka hal tersebut sebagai bukti tuntutan lembaga untuk merealisasikan kemampuan pegawai. Kemampuan pegawai ini pula dalam menggunakan alat bantu dalam proses pelayanan dapat mempermudah pelayanan tanpa mengandalkan bantuan pegawai lain.

2) Memiliki standar pelayanan yang jelas

Pelayanan Kepegawaian Dinas Pendidikan Kabupaten Probolinggo sudah memiliki standar pelayanan yang jelas sesuai dengan SOP yang berlaku. Lebih jelasnya pegawai Pelayanan Kepegawaian hanya menjalankan tugasnya sesuai dengan SOP, namun untuk pembuatan SOP ada tim sendiri untuk menyusun standar-standar tersebut. Begitu juga dengan masyarakat sebagai pengguna layanan tidak semuanya mengetahui standar Pelayanan Kepegawaian. Memiliki Standar Pelayanan Publik memang penting untuk pedoman pegawai dalam melayani pengguna layanan dalam proses pelayanan karena dengan berpatokan kepada standar pelayanan, proses pelayanan dapat berjalan dengan baik guna mencapai tujuan pelayanan khususnya Pelayanan Kepegawaian Dinas Pendidikan Kabupaten Probolinggo. Karena Pelayanan Kepegawaian 
Al-Tanzim : Jurnal Manajemen Pendidikan Islam

E-ISSN: 2549-5720 P-ISSN: 2549-3663

March 2019, Vol. 03 No. 01, p. 169-197

bttps: / / journal.unuja.ac.id/ index.php/ al-tanzim

hanya menyusun rencana dan program kerja operasional kegiatan pelayanan administrasi kepegawaian.

\section{c. Dimensi Responsiviness}

Dalam dimensi responsiviness ini terkait dengan sikap pegawai Pelayanan Kepegawaian Dinas Pendidikan Kabupaten Probolinggo yang mau mendengar atau merespon keluhan masyarakat dan mampu memberikan pelayanan dengan cepat dan tepat.

1) Pegawai mampu memberikan pelayanan yang cepat dan tepat

Unsur kecepatan dan ketepatan dalam memberikan layanan merupakan hal yang diharapkan oleh penerima layanan yang harus dipenuhi oleh pegawai Pelayanan Kepegawaian. Jikalau ada kendala dari permintaan berkas pengguna layanan tidak bisa hari itu juga diambil maka pegawai Pelayanan Kepegawaian akan memberikan pengertian dan menjanjikan waktu tertentu.

2) Pegawai mau mendengar keluhan pengguna layanan

Pelayanan Kepegawaian Dinas Pendidikan Kabupaten Probolinggo sebagai penyedia layanan merespon setiap pengguna layanan yang 
Al-Tanzim : Jurnal Manajemen Pendidikan Islam

E-ISSN: 2549-5720 P-ISSN: 2549-3663

March 2019, Vol. 03 No. 01, p. 169-197

https:// ejournal.unuja.ac.id/ index.php/al-tanzim

mempunyai keluhan terkait proses pelayanan. Pegawai Pelayanan Kepegawaian akan memberikan arahan dengan jelas dan mengerti usaha serta kebutuhan mereka jika mendapati keluhan dari pengguna layanan.

\section{d. Dimensi Assurance}

Unsur-unsur pokok yang dalam Pelayanan Kepegawaian Dinas Pendidikan Kabupaten Probolinggo dalam dimensi Assurance ada jaminan waktu, dan jaminan biaya dalam proses pelayanan.

1) Pegawai memberikan jaminan tepat waktu dalam pelayanan

Pegawai Pelayanan Kepegawaian Dinas Pendidikan Kabupaten Probolinggo memberikan jaminan tepat waktu dalam pelayanan dengan diusahakan diselesaikan pegawai tepat waktu. Umumnya penyelesaian berkas hanya butuh waktu kurang lebih satu hari setelah pengajuan berkas atau dua kali balik ke kantor Pelayanan Kepegawaian Dinas Pendidikan Kabupaten Probolinggo.

2) Pegawai memberikan jaminan biaya dalam pelayanan

Jaminan biaya yang diberikan Pelayananan Kepegawaian Dinas Pendidikan Kabupaten Probolinggo kepada pengguna layanan telah 
Al-Tanzim : Jurnal Manajemen Pendidikan Islam

E-ISSN: 2549-5720 P-ISSN: 2549-3663

March 2019, Vol. 03 No. 01, p. 169-197

https:/ / ejournal.unuja.ac.id/ index.php/ al-tanzim

dianggarkan dengan adanya program yang ditetapkan oleh Dinas Pendidikan untuk pelayanan administrasi pada tahun 2019. Tak hanya itu, merujuk pada visi Pelayanan Kepegawaian juga telah menetapkan tidak ada pungutan biaya terhadap administrasi apapun yang dibutuhkan masyarakat.

\section{e. Dimensi Emphaty}

Dalam dimensi ini, Pelayananan Kepegawaian Dinas Pendidikan Kabupaten Probolinggo memiliki unsur baik untuk pelayanan melalui mendahulukan kepentingan publik daripada pribadi, tidak membeda-bedakan pengguna layanan, memberikan sikap yang sopan, santun, ramah, dan menghargai pengguna layanan. Ketiga hal tersebut sangat tidak baik jika terjadi dalam Pelayananan Kepegawaian untuk keberlangsungan pelayanan karena dapat menimbulkan rasa tidak nyaman bahkan hingga tidak menyukai dengan pelayanan yang diberikan.

1) Pegawai mendahulukan kepentingan publik daripada pribadi

Pelayananan Kepegawaian Dinas Pendidikan Kabupaten Probolinggo memprioritaskan pengguna layanan dalam proses pelayanan. Jika pengguna layanan tidak merasa didahulukan akan timbul keluhan dan akan memberikan citra 
Al-Tanzim : Jurnal Manajemen Pendidikan Islam

E-ISSN: 2549-5720 P-ISSN: 2549-3663

March 2019, Vol. 03 No. 01, p. 169-197

https: / / ejournal.unuja.ac.id/ index.php/al-tanzim

yang buruk bagi lembaga Pelayanan Kepegawaian Dinas Pendidikan Kabupaten Probolinggo.

2) Pegawai tidak mendeskriminasi atau membedabedakan pengguna layanan

Pegawai Pelayananan Kepegawaian Dinas Pendidikan Kabupaten Probolinggo tidak pernah membeda-bedakan dalam melayani pelanggan. Semua pengguna layanan dilayani dengan sama oleh pegawai Pelayanan Kepegawaian. Bersikap adil kepada setiap pengguna layanan merupakan solusi dan penerapan yang baik untuk pelayanan kepegawaian sehingga dapat menghindari mendeskriminasi pengguna layanan.

3) Pegawai memberikan sikap sopan, santun, dan ramah dalam pelayanan

Unsur ini yang menjadi acuan Pelayananan Kepegawaian Dinas Pendidikan Kabupaten Probolinggo terhadap masyarakat untuk merasa nyaman dan senang dengan pelayanan yang diberikan. Sebagai penyedia layanan, Pelayananan Kepegawaian sudah seharusnya memberikan jaminan sikap yang baik dengan sopan, santun serta ramah kepada siapapun pengguna layanan. 
Al-Tanzim : Jurnal Manajemen Pendidikan Islam

E-ISSN: 2549-5720 P-ISSN: 2549-3663

March 2019, Vol. 03 No. 01, p. 169-197

https:/ / ejournal.unuja.ac.id/ index.php/ al-tanzim

\section{KESIMPULAN}

Setelah melakukan serangkaian penelitian, pemaparan data, dan analisis yang peneliti lakukan pada Pelayanan Kepegawaian di Dinas Pendidikan Kabupaten Probolinggo, maka dapat ditarik kesimpulan dari penelitian ini bahwa Manajemen strategi yang dilakukan Dinas Pendidikan Kabupaten Probolinggo juga diterapkan pada pelayanan kepegawaian dengan berpedoman kepada RPJP Propinsi dan RPJMD Kabupaten Probolinggo dan visi Dinas Pendidikan Kabupaten Probolinggo sendiri. Manajemen strategi ini ditempuh dengan proses tahapan formulasi/perencanaan strategi, implementasi/pelaksanaan strategi, dan evaluasi strategi. Mutu pelayanan kepegawaian Dinas Pendidikan Kabupaten Probolinggo setelah dilakukan manajemen strategi sudah terbilang baik dan memuaskan yang terbukti dengan dirasakan langsung oleh para PNS dan pegawai aparatur pemerintah di lingkungan Dinas Pendidikan Kabupaten Probolinggo. 
Al-Tanzim : Jurnal Manajemen Pendidikan Islam

E-ISSN: 2549-5720 P-ISSN: 2549-3663

March 2019, Vol. 03 No. 01, p. 169-197

https:// ejournal.unija.ac.id/ index.php/al-tanzim

\section{DAFTAR PUSTAKA}

Hasan Baharun, Z. (2017). Manajemen Mutu Pendidikan: Ikhtiar dalam Meningkatkan Mutu Pendidikan Madrasah melalui Pendekatan Balanced Scorecard. Tulungagung: Akademia Pustaka.

Hisbanarto, Y. \& V. (2014). System Informasi Manajemen Pendidikan. Yogyakarta: Graha Ilmu.

Jailani. (2013). Pelayanan publik: kajian pendekatan menurut perspektif islam. JURNAL AL-BAYAN, 19(27), 93-110.

Keputusan Menteri Pendayagunaan Aparatur Negara No. 63 Tahun 2003 Tentang Pedoman Umum Penyelenggaraan Pelayanan Publik. (n.d.).

Kurniawan, R. C. (2016). TANTANGAN KUALITAS PELAYANAN PUBLIK PADA PEMERINTAH DAERAH. Jurnal Ilmiah Administrasi Publik Dan Pembangunan, 7(1), 15-26.

LAN, P. K. M. P. (2009). Standar Pelayanan Publik Langkahlangkah Penyusunan (Cet-1). Jakarta: LAN.

Mundiri, A. (2016). STRATEGI LEMBAGA PENDIDIKAN ISLAM DALAM MEMBANGUN BRANDING IMAGE. Pedagogik; Jurnal Pendidikan, 3(2), 58-72.

Nilasari, S. (2014). Majamen Strategi Itu Gampang. Jakarta Timur: Dunia Cerdas. 
Al-Tanzim : Jurnal Manajemen Pendidikan Islam

E-ISSN: 2549-5720 P-ISSN: 2549-3663

March 2019, Vol. 03 No. 01, p. 169-197

bttps: / / journal.unuja.ac.id/ index.php/ al-tanzim

Pratama, M. H. (2015). STRATEGI MENINGKATKAN KUALITAS PELAYANAN PUBLIK ( Studi Deskriptif tentang Strategi UPTD Pengujian Kendaraan Bermotor Tandes Kota Surabaya dalam Meningkatkan Kualitas Pelayanan Pengujian Kendaraan Bermotor ). Kebijakan Dan Manajemen Publik, 3(3), 90-98.

Saleh, S. (2016). PELAYANAN ADMINISTRASI KEPEGAWAIAN. Junal Eklektika, 4(1), 3-19.

Satispi, T. \& E. (2018a). Teori dan Perkembangan Manajemen Pelayanan Publik. Tangerang Selatan: UMJ PRESS.

Satispi, T. \& E. (2018). Teori Dan Perkembangan Manajemen Pelayanan Publik. Tangerang Selatan: UMJ PRESS.

Satispi, T. \& E. (2018b). Teori Dan Perkembangan Manajemen Pelayanan Publik. Tangerang Selatan: UMJ PRESS.

Taufiqurokhman. (2016). Manajemen Strategik. Jakarta Pusat: Fakuktas Ilmu Sosial \& Ilmu Politik Universitas Dr. Moestopo Beragama.

Wijaya, T. (2013). Metode Penelitian Ekonomi dan Bisnis (Teori \& Praktik). Yogyakarta: Graha Ilmu. 